Abstract

\title{
Opuntia Ficus-Indica a Mediterranean Diet Product †
}

\author{
Nardjes Toma Mouas, Zahia Kabouche, Nibel Bellel and Lina Kamar Chertout
}

Citation: Mouas, N.T.; Kabouche, Z.; Bellel, N.; Chertout, L.K. Opuntia Ficus-Indica a Mediterranean Diet Product. Proceedings 2021, 68, $\mathrm{x}$. https://doi.org/10.3390/xxxxx

Published: date

Publisher's Note: MDPI stays neutral with regard to jurisdictional claims in published maps and institutional affiliations.

Copyright: (c) 2021 by the authors. Submitted for possible open access publication under the terms and conditions of the Creative Commons Attribution (CC BY) license (http://creativecommons.org/licenses/by/4.0/).
Université frères Mentouri-Constantine 1, Laboratoire d'Obtention de Substances Thérapeutiques (LOST), Campus Chasbet Ersas, 25000 Constantine, Algérie;

$+\quad$ Presented at the 1st International Electronic Conference on Biological Diversity, Ecology and Evolution, 15-31 March 2021; Available online: https://bdee2021.sciforum.net/.

\begin{abstract}
During last decades, several researches and scientific studies were conducted on the " Pontiac ficus indica » a wild edible plant which the fruit is commonly known as prickly pear, promoting its nutritional value, due to a rich composition in polyphenols, polyunsaturated fatty acids, vitamins and amino acids. The current work intends to highlight uses of hole plant parts in different fields such as medical field including anti-inflammatory, antioxidant, antibacterial, antiulcer, dietetic, anticancer and antidiabetic activities. Pontiac ficus indica is also wildly used in the culinary field as jam and food coloring; in the agronomic and ecological field as regenerator of exhausted soils; as supplement in fodder use, and in dermacosmetics and parapharmaceutical industry in shampoo and anti-wrinkle skin creams. However; the use of this plant remains very limited. Consequently; this work is a global revue came to open the way for other more targeted investigations; particularly in Biotechnology
\end{abstract}

Keywords: Pontiac ficus indica, chemical composition, nutritional value, biological activities

\section{Introduction}

Seasonal fruits and vegetables are main elements in Mediterranean diet, basically based on local products such as prickly pear. This spontaneous and invasive specie adapts to the harshest climatic conditions which permitted its implantation in the Mediterranean region since middle ages, and becomes a far product commonly used as fruit, forage or traditional remedy.

In fact nowadays, nutrition becomes crucial element in health prevention, thus establish and follow national nutritional recommendations and balanced diet could decrease and prevent developpement of several chronicle and degenerative diseases related to nutrition and extend life expectancy, in this context Mediterranean diet scientifically proved its efficiency in prevention of many of it [1-4].

The present mini review aims to promote renewable local bioresouces for an agriculture based on responsible and durable Eco-economy.

\section{Experiments}

Intensive and rigors researches using several national and international references (articles, books, reviews in Electronic databases:MDPI, Science Direct,Springler, ACS, RS, PubMed, Pub Chem, Google Scholar...) were performed since 1981 until our days, to study evolution of scientific research on Opuntia ficus-indica in time, and how it performs in regard of varying fields: ethnobotany, ethnopharmacology, Chemistry, Nutrition, Biological and Biotechnogical applications in order to extract maximum informations concerning investigated plant.

\section{Results and discussion}


According to histogram (Fig.1), which represents reviewing investigations results; scientific researches are generally increasing, highlighting by the way growing interest, currency and relevance of studied plant. Obtained results, lead to enumerate achievements and lacks which could be interesting to investigate in the future.

\subsection{Origin and geographic distribution}

Opuntia ficus-indica is Mexic native, [5-6] and grows in the wild in arid and sub-arid regions in south america Africa and mediteranean area. Nowadays, it isconsidred as a cosmopolit plant introduced and cultivated in more than 30 countries around the world, and maily consumed as fruit or forage in our contry Algeria.

\subsection{Nutritional value}

Opuntia ficus-indica is a providential plant, fruits are rich in vitamin $C$ and young cladodes rich in copper, magnesium and iron are consumed as salad. Glucids are essential energy source with $44 \mathrm{kcal} / 100 \mathrm{~g}$, it is considered as moderately energetic [7].

\subsubsection{Chemical composition}

Chemical composition is not absolute and depends on several ecological factors: variety, sol, season and age of the plant. [8].

- Water content

This value is not constant and very (81-90\%) according to the climate and season humidity

- Glucids

Glucose and fructose are the main monosaccharide present in pulp fruit [9].

Glucids average content is (10,16-16,61\%) [10], related and controlled by agronomic and environmental factors as well as maturity stage.

- Fatty acids

Several researches and chromatographic analysis exhibit puntia ficus-indica as an excellent fatty acids source, particurly linolénique, oléique and palmitique acids in the whole fruit with a high level of linoléique oméga-6 acid in seeds oil [11].

- Minerals

The plant is rich in oligoelements (0.28 -0.39\%) with a predominance of Potassium, Calcium and Magnesium [9, 12].

- Fibers

Pulp fiber content is (0.02-3.15 g /100 g dry weight) [13,14], pectin is in part responsible of pulp viscosity which is an advantage in juice and jam production, fruit pulp pectine content is $(0,17-0,21 \%)$ but still not sufficient for gels production [10].

- Phenols

All plant parts (flowers, pulp, seeds, skin, leaves) are rich in phenols: flavols, flavones, phenols acids, but pulp still the richest one with $218 \mathrm{mg} / 100 \mathrm{~g}$ followed by seeds with $89 \mathrm{mg} / 100 \mathrm{~g}$ [11].

Quercétine is the main flavonoïd in the plant followed by isorhamnétine, lutéoline and kaempférol. Whereas there is a predominance of nicotiflorine $(146.5 \mathrm{mg} / 100 \mathrm{~g})$ in cladodes.

- Betalains

Opuntia ficus indica contains bétalaines, a hydrosoluble nitrogen based pigments, responsible the plant color; which also give strong antioxidant proprieties $[15,16]$.

- Carotenoids

$\beta$ - carotene a liposoluble pigment present in small amounts in fruit chloroplast cells (2.6-478 $\mu \mathrm{g}$ en $100 \mathrm{~g}$ fresh weight).

- Vitamins

Plant seed oil is reach in lipo tocophérols, particurly isomorphes $\Upsilon$ et $\alpha$-tocophérol [17].

- Phytosterols 
According to El- Moustafa et al, (2014), fruit skin is the richest in phytosterols (Campestérol, Stigmastérol, Lanostérols, $\beta$-Sitostérol, Ergostérol).

\subsection{Biological activities}

\subsubsection{Antioxydant activity}

Several phytochemical studies were realized on different plant' parts showing its phenol profile which confers to the plant a very interesting antioxidant activity [18].

- Antioxydant activity of juice

DPPH test realized on fruit juice extract exhibit phenols, flavonoids, betalains pigment like as having an antiradical activity even higher than vitamin C. Besides, secondary metabolites have synergetic action in crud juice, and purpul juices are more actif than yellow/orange ones [19].

- Antioxydant activity of seeds oil

Seeds oil antioxidant activity was measured by DPPH and $\beta$-carotène bleaching tests, which highlighted an important dose-depending activity similar to that of ascorbic acid and hydroxytoluènebutylé[20].

- Antioxydant activity of Leaves

Opuntia ficus indica leaves' ethanol extract antioxidant activity is related to an important phenols content and was estimated for DPPH, superoxide anions (O2 * $\left.{ }^{-}\right)$and hydroxyls $\left(\mathrm{OH}^{*}-\right)$ radicals, and a great capacity to protect plasma DNA from breaking up by hydroxyl radicals [21].

\subsubsection{Atimicrobial activity}

An important inhibiting effect against two gram negative bacterial strains Staphylococcus aureus and Escherichia coli in addition to a fungi Candida albicans was reported [22].

\subsubsection{Antiulcer activity}

Pontiac focus indicia cladodes are used in traditional medicine to treat gastric ulcer, in fact its richness in fiber (pectin polysaccharides) stimulates gastro-intestinal mucus regeneration [29].

\subsubsection{Antiflamatory activity}

Several studies reported analgesic and antiflamatory activities of Opuntia gender either on lyophilized cladodes or its phytosterol extracts, more over $\beta$-sitostérol was identified as active principal of such activity in cladods [30].

\subsubsection{Cytotoxic activity}

Betanines (red pigment belonging to betacyanines) present in the plant, pocess an important

Antioxidant and anticancer activities, so it can be used for prevention [25].

\subsubsection{Glecimic activity}

Opuntia fucus indica was used since ancient times by Mexicans as traditional remedy to treat diabetes, nowadays in vivo assays reported hypoglycemic effect of cladodes extract on rats either combined with insulin or not [26]. 


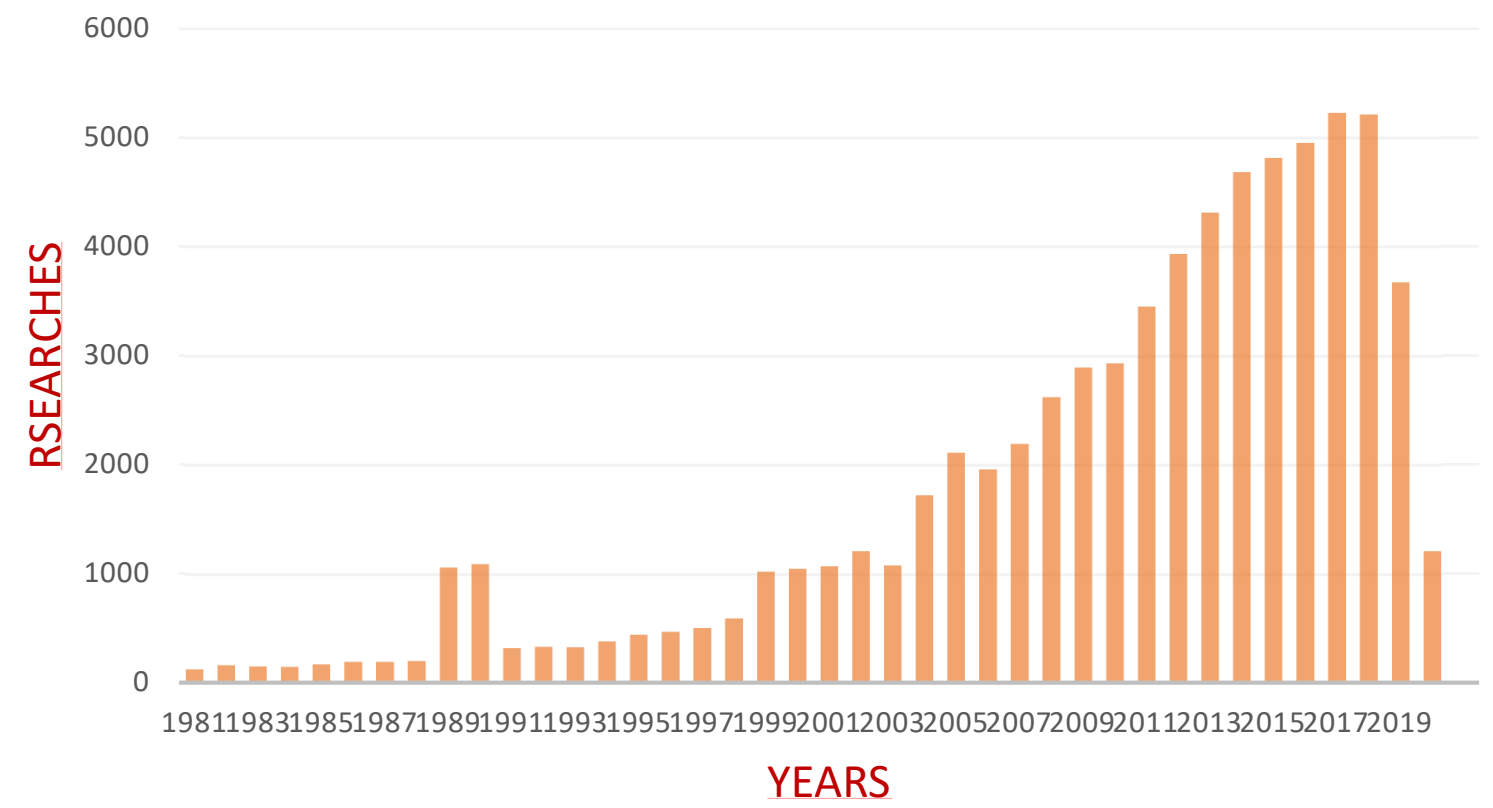

Figure 1. Evolution of researches number on Opuntia ficus indica between 1981 and 2019.

\section{Conclusions}

Opuntia ficus indica is a whispered plant in Mediterranean region, characterized by its remarquable adaptation to arid, sub-arid and tropical climates. An intensive mini review was conducted on the « Opuntia ficus indica » plant commonly known as prickly pear promoting its nutritional value, due to its rich composition in essential nutriments.

The current work intends to highlight the use of the fruit in different fields such as; the medical field including anti-inflammatory, antioxidant, antibacterial, antiulcer, anticancer and antidiabetic activities. It can be used in the culinary field as jam and food coloring; and also employed in the agronomic and ecological field against erosion and as regenerator of exhausted soils; or supplement in fodder use. And in the cosmetic and parapharmaceutical industry which they are integrated in the composition of shampoo and anti-wrinkle skin creams.

Acknowledgments: Authors would like to thank Algerian Ministry of Higher Education and Scientific Research DGEFS, and the Algerian Directorate General for Scientific Research and Technological Development DGRSDT for finical fund.

Author Contributions: M.T.N. conceived, designed, analyzed the data and wrote the paper; N.B. and L.C. performed the review; Z.K. scientific assistance.

Conflicts of Interest: The authors declare no conflict of interest. The founding sponsors had no role in the design of the study; in the collection, analyses, or interpretation of data; in the writing of the manuscript, and in the decision to publish the results.

\section{References}

1. De Lorgeril, M.; Salen, P.. Régime méditerranéen et maladies cardiovasculaires. Phytothérapie. 2015; 13, 91-95.

2. Estruch, R., Ros, E., Salas-Salvadó, J., Covas, MI. (2013). Primary prevention of cardiovascular disease with a Mediterranean diet. N Engl J Med. 14: 1279-90.

3. Tektonidis,TG.; Åkesson,A.; Gigante,B. Wolk,A.; Larsson,SC. (2015). A Mediterranean diet and risk of myocardial infarction, heart failure and stroke:population-based cohort study. Atherosclerosis. 243, 93-98. 
4. Knight, A,. Bryana; C., Murphyb, K. (2016). cIs the Mediterranean diet a feasible approach to preserving cognitive function and reducing risk of dementia for older adults in Western countries; New insights and future directions.

5. Reynolds, SG., Arias-Jimenez, E., Mondrago, C.; Perezgonzales, S. (2003). El nopal (Opuntia spp.) como forraje. Estudio FAO Produccion y Proteccion Vegetal. 169: 344-345.

6. Barbera, G., Carimi,F., Inglese, P. (1992). Physical, morphological and chemical changes during fruit development and ripening in three cultivars of prickly pear, Opuntia ficus. (L.) Miller. J. Hortic. Sci, 3: 307-312.

7. Piga,A. (2004). Cactus pear: A fruit of Neutraceutical and Functional Importance. J.PACD 9-22.

8. Stintzing, FC., Carle,R. (2005). Cactus stems (Opuntia spp.): A review on their chemistry, technology, and uses. Mol. Nutr. Food Res. 49: 175-194

9. Jiménez-Aguilar, DM., Mújica-Paz, H.; Welti-Chanes, J. (2014). Phytochemical Characterization of Prickly Pear (Opuntia spp.) and of its Nutritional and Functional Properties: A Review. Current Nutrition \& Food Science. 10: 57-69.

10. Saenz, C. (2000). processing technologies: an alternative for cactus pear (Opuntia spp.) fruits and cladodes. Journal of Arid Environments, 46: 209-225.

11. El-Mostafa, K., El Kharrassi,Y., Badreddine. A., Andreoletti, P. (2014). Nopal Cactus (Opuntia ficus-indica) as a Source of Bioactive Compounds for Nutrition. Health and Disease review, Molecules, 19: 14879-14901.

12. Medina, EM., Rodriguez, EM., Romero, C. (2007) . Chemical characterization of Opuntiadillenii and Opuntia ficus indica fruits. Food Chemistry 103, 38-45.

13. Rodriguez, EM., Romero, C. (2007). Chemical characterization of Opuntia dillenii and Opuntia ficus indica fruits. Food Chemistry. 103, 38-45.

14. Pena-Valdivia, CB., Trejo, C., Arroyo-Pena,VB., Sanchez-Urdaneta,AB., Morales, RB.(2012) .Diversity of Unavailable Polysaccharides and Dietary Fiber in Domesticated Nopalito and Cactus Pear Fruit. Chemistry \& Biodiversity. $9: 1599-1609$.

15. Albano C, Negro C, Tommasi N, Gerardi C, Mita G, Miceli A, et al.(2015). Betalains, phenols and antioxidant capacity in cactus pear [Opuntia ficus-indica (L.) mill.] fruits from Apulia (South Italy) genotypes. Antioxidants.4(2):269-280

16. Butera D, Tesoriere L, Di Gaudio F, Bongiorno A, Allegra M, Pintaudi AM, et al.(2002). Antioxidant activities of sicilian prickly pear (Opuntia ficus indica) fruit extracts and reducing properties of its betalains: Betanin and indicaxanthin. Journal of Agricultural and Food Chemistry. 50(23):6895-6901.

17. Ramadan, MF., Morsel, JT. (2003). Oil cactus pear (Opuntiaficus-indica).Food.Chem.82 : 339-345.

18. Maataoui, BS., Hmyene, A., Hilali, S. (2006).Activités anti-radicalaires d'extraits de jus de fruits du figuier de barbarie (Opuntia ficus-indica). Leban. Scien. J., $7: 3-8$.

19. Sharma Om, P., Bhat,TK. (2009). DPPH antioxidant assay revisited. Food. Chem. 113: 1202-1205.

20. Wei, L., Yu-Jie, F., Yuan-Gang Z, Mei-Hong, T., Nan, W., Xiao-Lei, L., Su, Z. (2009).Supercritical carbon dioxide extraction of seed oil from OpuntiadilleniiHaw and its antioxidant activity. Food. Chem. 114 : 334-339.

21. Li, HB., Cheng, KW., Wong, CC., Fan, KW., Chen, F., Jiang, Y. (2007). Evaluation of antioxidant capacity and total phenolic content of different fractions of selected microalgae. Food chemistry. $102:$ 771-776.

22. Somaie, S., Kariminik, A., Hasanabadi, Z. (2013). Antimicrobial activity of methanol extract of OpuntiastrictaF. Intern.Rese. J. Appl. Bas. Scien., 7 : 907-910.

23. a) Galati, EM., Monforte, MT., Tripodo, MM., d'Aquino, A., Mondello, MR. (2001). Antiulcer activity of Opuntia ficus indica (L.) Mill. (Cactaceae):ultrastructural study. Journal of Ethnopharmacology. 76: 1-9.

b) Galati; EM., S., Pergolizzi, N., Miceli, MT., Monforte, MM, Tripodo. (2002). Study on the increment of the production of gastric mucus in rats treated with Opuntia ficus indica (L.) Mill. Cladodes.Journal of Ethnopharmacology. 83: 229-233.

c) Galati, EM., Mondello, MR., Giufferida, D., Dugo, G., Miceli, N., Pergolizzi, S., Taviano, MF. (2003). Chemical characterization and biological effects of Sicilian Opuntia ficus indica (L.) Mill. Fruit juice: antioxidant and antiulcerogenic activity. J. Agric. Food Chem. 51: 4903-4908.

24. a)Park, EH., Kahng, JH., Paek, EA. (1998). Studies on the pharmacological actions of cactus: identification of is antiinflammatory effect. Arch. Pharm. Res. 21: 30-34. 
b)Park, EH., Kahng, JH., Lee, SH., Shin, KH.(2001). An anti-inflammatory principle from cactus.Fitoterapia, 72:288290.

25. Kapadia, GJ., Tokuda, H., Konoshima; T., Nishino H (1996). Chemoprevention of lung and skin cancer by Beta vulgaris (beet) root extract. Cancer Lett. 100: 211-214.

26. Augusto TG., Genaro GO., Puebla-Pdrez AM., Huizar-Contreras MD., Munguia-Mazariegos-Mdel R., Mejia-Arreguin S., Calva E. (1996). A purified extract from prickly pear cactus (Opuntia fuliginosa) controls experimentally induced diabetes in rats. J. Ethnopharmac, $55: 27-33$. 